DOI 10.22363/2618-897X-2020-17-2-215-220

Abstracts

\title{
Chinese Insertions Functioning in English: A Comparative Approach to Fiction and Non-Fiction Texts
}

\author{
T.A. Lupachyova, V.V. Bereznitskaya \\ Far Eastern Federal University \\ 8, Sukhanova St., Vladivostok, 690091, Russian Federation
}

The present article is devoted to the comparative analysis of Chinese insertions functioning in fiction and non-fiction written in English based on the works of Amy Tan and Peter Hessler. As the research showed, the leading function of insertions in non-fiction was documentary function, whereas in fiction it was the function of ethnic coloring and the function of hero speech characteristics. The functions in the analyzed texts overlap and complement one another. Structurally the insertions in non-fiction feature words and phrases, in fiction they vary from interjections to significant parts of texts.

Key words: foreign insertions, functions of insertions, fiction in English, non-fiction in English

\section{Article history:}

Received: 03.02.2020

Accepted: 05.04.2020

Moderator: U.M. Bakhtikireeva

Conflict of interests: none

\section{For citation:}

Lupachyova, T.A., and V.V. Bereznitskaya. 2020. "Chinese Insertions Functioning in English: a Comparative Approach to Fiction and Non-Fiction Texts". Polylinguality and Transcultural Practices, 17 (2), 215-220. DOI 10.22363/2618-897X-2020-17-2-215-220

(C) Lupachyova T.A., Bereznitskaya V.V., 2020

This work is licensed under a Creative Commons Attribution 4.0 International License 


\title{
Китайские вкрапления в английском языке: сравнительный подход к художественным и научно-популярным текстам
}

\author{
Т.А. Лупачева, В.В. Березницкая \\ Дальневосточный федеральный университет \\ Российская Федерация, 690091, Владивосток, ул. Суханова, 8
}

\begin{abstract}
Настоящая статья посвящена сравнительному анализу функционирования китайских вкраплений в англоязычной художественной и документальной прозе на примере произведений Эми Тэн и Питера Хесслера. Как показало исследование, ведущей функцией вкраплений в документальной прозе является функция документализации, в художественной прозе - функция создания колорита и речевой характеристики персонажа. Функции, встречающиеся в текстах, накладываются и взаимно дополняют друг друга. Структурно вкрапления в документальной прозе представляют собой слова и фразы, в художественной прозе они варьируются от междометий до крупных отрезков текста.
\end{abstract}

Ключевые слова: иноязычные вкрапления, функции вкраплений, англоязычная художественная проза, англоязычная документальная проза

\section{История статьи:}

Дата поступления в редакцию: 03.02.2020

Дата принятия к печати: 05.04.2020

Модератор: У.М. Бахтикиреева

Конфликт интересов: отсутствует

\section{Для цитирования:}

Лупачева Т.А., Березницкая В.В. Китайские вкрапления в английском языке: сравнительный подход к художественным и научно-популярным текстам // Полилингвиальность и транскультурные практики. 2020. Т. 17. № 2. C. 215-220. DOI 10.22363/2618-897X-2020$17-2-215-220$

\section{Introduction}

The research of such linguistic phenomenon as foreign language inclusions lately has aroused a great interest among the linguists of different countries. Studying particular characteristics of speech occasional borrowings functioning in the recipient text both in general linguistic sense and in a complex of linguastylistical problems provides an opportunity to see the initial stage of borrowing in the dynamics. In spite of the problem scope there is still no single established definition of foreign insertions. The researchers discriminate the following characteristic features of foreign insertions: non-assimilation, grammatical non-assimilation, belonging to a foreign system, they are not fixed in the dictionaries of a recipient language, they are used by bilinguals. 
Quite often foreign insertions are considered together with such connected notions as loan-words, exoticisms, barbarisms. The term "foreign insertions" is the most general of them and, according to many researchers, includes some connected terms and can be mostly seen in special literature. Foreign insertions are distinguished from the connected notions by a greater non-assimilation by a recipient language, mostly foreign graphic transference and a greater volume of language units.

In the present paper by foreign insertions we understand foreign linguistic units, transliteration of foreign linguistic units as well as different volume units of the donor language (from interjections to text extracts) used according to the laws of the recipient language, which are surrounded by the elements of the borrowing language (English), non-assimilated or partly assimilated in the system of the borrowing language, but not codified in it [1. P. 270].

There is a great number of foreign insertions classifications based on various features (correlation with the systems of the donor language and the recipient language, the degree of connection with ethno-cultural character of the text content, source of borrowing, position in the text, its volume). During the analysis of the current classifications it turned out that the researchers count as foreign insertions not only full insertions in their foreign graphics, but also the parts of texts translated into the recipient language; not only words, but foreign letters inside words as well; not only linguistic phenomena not having ethic coloring, but also the elements having it. As a result, foreign insertions are being confused with exoticisms.

\section{Discussion}

The main reason of using foreign insertions of any volume is a language contact including code switching. Literary creativity, both fiction and non-fiction, can be considered a variety of a language contact. Notably, foreign insertions can be in the linguistic arsenal of a monolingual writer, not only a bilingual one.

The problem of foreign insertions functioning has been well-analyzed only on the material of fiction. Practically all the researchers have featured a nominative function, a function of creating a comic effect, a function of ethnic coloring, a function of speech individualization. Some investigators also differentiate a function of elaboration and semantics specification of a close word of the recipient text, a function of a character's emotional state rendering, a function of ethnic peculiarity and mythology, a function of narration metaphorization as well as linguareflexive, repressive, intermediary, excluding functions along with a euphemistic one, etc.

The majority of researchers have pointed out that the dominating functions in fiction are nominative function and ethnic coloring function.

In the present paper there has been made an attempt to make a comparative analysis of Chinese insertions functioning in fiction and non-fiction texts written in English. "River Town: Two Years on the Yangtze" by Peter Hessler was chosen as a non-fiction source. This book is considered to be the most significant work of this author and it contains a sufficient for this analysis number of foreign insertions. A fiction text is represented by Amy Tan's novel "The Hundred Secret Senses" abundant in the equivalent linguistic units. 
Let us now proceed to the description of Chinese insertions and the functions performed by them in the abovementioned pieces of work. We should immediately mention that both authors represent Chinese insertions in transliteration due to the fact that Chinese hieroglyphs would be perceived as too exotic and absolutely incomprehensible for the readers.

According to the structural features classification the majority of insertions found in non-fiction material are words.

"People everywhere talked about Gaige Kaifang, Reform and Opening, which included both increased contact with the outside world and the Capitalist-style economic reforms that Deng Xiaoping had initiated in 1978" [2].

Insertions-expressions and insertions-phrases can be also found. It turned out that insertions-interjections and insertions-sentences are not present in non-fiction text. On the contrary, they can often be found in fiction text and there they create a decorative and an emotive functions.

And when the wind blew, the mouths of the caves would sing wu!wu! - just like the voices of sad ladies who have lost sons [3. P. 43].

I heard a girl's voice say: "Gei wo kan" [3. P. 56].

This fact somehow signals that a set of functions delivered by foreign insertions in non-fiction is different from a set of functions in other genres. According to the subject classification insertions-toponyms and insertions-anthroponyms are most widely spread in the work under analysis. In the fiction the scope of insertions varies between interjections and text extracts. Both in fiction and non-fiction insertions are mostly represented by toponyms and anthroponyms, which is quite predictable, because they tie the narration to a certain place and time.

Whenever foreigners arrived in our province, everyone in the countryside - from Nanning to Guilin - talked about them [3. P. 35].

"My apartment was on the top floor of a building high on a hill above the Wu River. It was a pretty river, fast and clean, and it ran from the wild southern mountains of Guizhou province. Across the Wu River was the main city of Fuling, a tangle of blocky concrete buildings rising up the hillside" [2].

Let us now pass on to the foreign insertions functions performed in non-fiction. The majority of insertions (toponyms, anthroponyms, some realia) carry out the documentary function. Also the insertions perform nominative, euphemistic, culture oriented, linguareflexive, compensatory and separating functions. Herewith one insertion often performs several functions at the same time.

In the fiction describing a foreign situation the role of foreign insertions is not limited to sending a message. They appear in the text not only for nominative reasons, but also to perform aesthetic functions.

The stylistic potential of Chinese insertions on the background of English linguistic environment is contingent on their content as well as their unusual sound representation and exotic associations created by it. Semantic and stylistic functions performed by 
Chinese insertions overlap and complement each other, they comply with the imagery perspective of the fiction whole. For example, one insertion can be used in nominative function and create ethnic coloring at the same time. That is why to illustrate the phenomena the insertions where the given function was the leading one were selected.

Having got into the linguistic environment of the recipient text written in English, Chinese insertions perform a number of semantic and stylistic functions: nominative, specification, expressive, creating a comic effect, cacophemism transmission, ethic coloring and characteristics creation, leitmotif creation, depicting of characters emotional state, ethnic worldview and mythology peculiarity transmission, speech individualization. This is their main focus both in microcontexts and in the creative system of the whole book.

Thus, the undertaken analysis of foreign insertions performed on the material of fiction and non-fiction has allowed us to recognize the peculiarities of foreign insertions functioning in the present genres. In non-fiction the majority of Chinese insertions perform a documentary function due to which a realistic reproduction of events, factual authenticity is attained. In fiction the leading functions are the function of ethic coloring and speech characteristics function. In both genres the functions performed by foreign insertions can overlap. During the research it was noted that some functions can be the same in fiction and non-fiction (for example, nominative, culture oriented, euphemistic, separating), but some functions are specific for each genre in particular (speech individualization, comic effect creation, cacophemism transmission, leitmotif creation in fiction; documentary function in non-fiction).

\section{Conclusion}

Thus, we came to a conclusion that Chinese insertions different in structure can be found both in fiction and non-fiction. However, in non-fiction the insertions on the text level were not found. The majority of the functions performed by insertions in the texts conform with each other, however there are some genre differences in this sense. The undertaken analysis can present some interest for linguistics in general, namely for linguacontactology and linguastylistics. We see the perspectives of the research in further specification of functions performed by foreign insertions in the texts of different genres.

\section{References}

1. Kolomiets, S.V. 2012. "Inoyazychnye vkrapleniya v tekstakh russkikh reklamnykh soobshchenii". Vestnik KemGU 4 (52): 268-272. Print. (In Russ.)

2. Hessler. P. 2001. River Town: Two Years on the Yangtze. New York: Harper Perennial. 418 p. Print.

3. Tan, A. 1996. The Hundred Secret Senses. New York: Ivy Books. 406 p. Print.

\section{Bio Notes:}

Tatiana A. Lupachyova is a Candidate in Philology at the Department of Linguistics and Intercultural Communication of Far-East State University. E-mail: lupachyova@yandex.ru

Viktoriya V. Bereznitskaya is a M.A. in Philology at the Department of Linguistics and Intercultural Communication of Far-East State University. E-mail: lupachyova@yandex.ru 


\section{Сведения об авторах:}

Лупачева Татьяна Александровна - кандидат филологических наук, доцент, доцент кафедры лингвистики и межкультурной коммуникации Дальневосточного федерального университета. E-mail: lupachyova@yandex.ru

Березницкая Виктория Вячеславовна - магистр в области филологии кафедры лингвистики и межкультурной коммуникации Дальневосточного федерального университета. E-mail: lupachyova@yandex.ru 